\title{
Cushioning Capability Analysis of Seat Foundations Considering the Sitter's Anthropometric Dimensions
}

\author{
Lingling Hu, ${ }^{\mathrm{a}, *}$ Onder Tor, ${ }^{\mathrm{b}}$ Liming Shen, ${ }^{\mathrm{c}}$ Jilei Zhang, ${ }^{\mathrm{d}}$ Franklin Quin, ${ }^{\mathrm{d}}$ and \\ Xiaohong $\mathrm{Yu}^{\mathrm{a}}$
}

\begin{abstract}
Sitting comfort is primarily determined by the cushioning capability of the seat foundation. Limited literature has been found related to the effects that different sized human buttocks had on the cushioning capability of the seat foundation. Moreover, there is no testing method specialized to measure the load-deformation behavior of foam cushions that imitates the sitting behavior between indenters with different sizes and seat support. This study investigated the effects of various indenter diameters $(20 \mathrm{~cm}$, $30 \mathrm{~cm}, 36 \mathrm{~cm}, 41 \mathrm{~cm}, 51 \mathrm{~cm}$, and $58 \mathrm{~cm}$ ), foam stiffness levels (high and low), and seat bases (spring versus solid flat panel) on the compressive load-deformation behavior of upholstered seat foundations. The loaddeformation curves of all the tested foam-seat base combinations exhibited three typical regions, i.e., linear elasticity, plateau, and densification, when subjected to the loads applied through different indenter diameters. Statistical results indicated that the primary effects of the indenter diameter, foam stiffness level, and seat base had significant effects on the spring constants, which represented the slopes of lines in these three regions. In addition, a regression technique was proposed to derive power equations for the estimation of the spring constants of a seat foundation as a function of the indenter diameter, foam material stiffness, and seat base type.
\end{abstract}

Keywords: Polyurethane foam; Seat foundation; Upholstered furniture; Indenter diameter; Foam stiffness

Contact information: a: School of Engineering, Zhejiang A\&F University, Hangzhou, Zhejiang 311300 China; b: Department of Forest Industry Engineering, Kastamonu University, Kastamonu, Kastamonu 999042 Turkey; c: Research and Development Center, Xilinmen Furniture Co. Ltd., Shaoxing, Zhejiang 312000 China; d: Department of Sustainable Bioproducts, Mississippi State University, Starkville, MS 39759 USA; *Corresponding author: radiant00@163.com

\section{INTRODUCTION}

Polyurethane (PU) foams covered with either fabric or leather for use as a surface cushion, in conjunction with springs installed in the seat base, are commonly used as the seat foundation of a piece of upholstered furniture. This allows for the conforming of the seat surface to the contour shape of the sitter's buttocks and prevents a concentration of pressure being applied on the buttocks (Ebe and Griffin 2001; Grujicic et al. 2009; Jucienè and Vobolis 2013). Correct designing of a seat foundation, i.e., selecting the right combination of foam and seat base type in terms of their stiffness combination, can provide a sitter with a comfortable sitting experience, e.g., feeling soft or hard, bottoming-out of the seat, as well as seat postural stability and postural control (Todd et al. 1998; Ebe and Griffin 2000; Xu et al. 2015; Chen et al. 2017; Gao et al. 2018). This is primarily due to the sitters' subjective satisfaction of sitting comfort being determined by the cushioning 
capability of the seat foundation (Ebe and Griffin 2000; Grujicic et al. 2009; Li 2017; Li et al. 2018).

The load-deformation behavior of seat cushions is commonly evaluated in the manner described in the previous studies by Todd et al. (1996), Dionne et al. (1998), Smardzewski et al. (2010), Oh et al. (2016), and Li (2017), who all reference ASTM standard D3574-17 (2017), i.e., using a flat circular metal plate (20 cm in diameter) as the indenter for compressing cushions. The load-deformation behavior measured by using this standard procedure has led to the results being different from those experienced by the human subjects in the real sitting situation, because it was concluded that the sitting area is the most significant factor in evaluating human subject sitting (Swearingen et al. 1962; Grujicic et al. 2009; Smardzewski et al. 2010; Smardzewski 2013). The reproduction of service loads and ergonomics are significantly important in terms of the success of the performance tests for humans in relation to different types of seats (Lee and Ferraiuolo 1993; Li 2017). The development of realistic performance tests has been extensively studied in order to investigate the load-deformation behavior of vehicle seats, pilot seats, and wheelchairs (Sprigle et al. 1990a,b; Shen and Vertiz 1997; Sims and Bennett 1998; Smardzewski et al. 2010; Kim et al. 2014; Li 2017; Hu et al. 2016; Li et al. 2017, 2018; Demirel and Tuna 2019a,b)

Several researchers with an interest in seat applications changed the geometries of the PU foam and indenter by using ASTM standard D3574-17 (2017). Sims and Bennett (1998) found that the geometry of the PU foam was an important factor in terms of its loaddeformation behavior. Specifically, matching the cushion surface contour to the buttocks' shape resulted in less tissue distortion and lower interface pressures (Sprigle et al. 1990a). Shen and Vertiz (1997) reported that the shape of the human subject buttocks directly affected the load-deformation behavior of car seats tested with a rigid butt-form indenter. Smardzewski et al. (2010) indicated that one of the methods for achieving the greatest comfort of the sitter was to adjust the stiffness of the seat elastic systems to the physicmechanical properties of the sitter's body. Kim et al. (2014) reported that when the testing dummy weight increased, the stiffness and loss factor of the tested cushion also increased.

These studies have led to the development of test indenters to reproduce loads occurring in human subjects, in terms of people with average body dimensions. However, limited literature has been found on the investigation of the effects of different sized human buttocks on the load-deformation behavior of the seat foundation. In addition, there is no specialized testing method to measure the load-deformation behavior of foam cushions that imitates sitting behavior in terms of different sized indenters and seat support.

The primary objective of this study was to evaluate the effect of the sitting area on the load-deformation behavior of upholstered seat foundations using different sized indenters, which represented different human hip sizes. Therefore, the specific objectives were to: 1) investigate the effect of the indenter size on the stiffness of the upholstered seat foundations; 2) investigate the effect of the stiffness property of foam materials (serving as the cushion for an upholstered seat foundation) on the stiffness of the upholstered seat foundations; and 3) investigate the effect of the seat base type on the stiffness of the upholstered seat foundations. It is believed that the results from this study can help furniture manufactures design their products to meet different sitting experiences demanded by their customers in terms of sitting ride, the hardness or softness of a seat foundation, etc. 


\section{EXPERIMENTAL}

\section{Participants}

Five healthy human subjects who represented five different body mass index (BMI) levels (WHO 2006) were recruited and their anthropometric measurements, i.e., weight, height, BMI, and hip width, were recorded (as shown in Table 1). Ethical approval was given by the Mississippi State University Institutional Review Board. Written informed consent was received from all participants.

Table 1. Summary of the Major Anthropometric Information Related to the Selection of Test Indenter Diameters

\begin{tabular}{|c|c|c|c|c|}
\hline $\begin{array}{c}\text { BMI Level } \\
\text { (weight range }(\mathrm{kg}))\end{array}$ & Weight $(\mathrm{kg})$ & Height $(\mathrm{m})$ & BMI $\left(\mathrm{kg} / \mathrm{m}^{2}\right)$ & Hip Width $(\mathrm{cm})$ \\
\hline Underweight (38-72) & 47 & 1.60 & 18.4 & 30 \\
\hline Normal (41-89) & 75 & 1.78 & 23.9 & 36 \\
\hline Overweight (54-111) & 98 & 1.82 & 29.5 & 41 \\
\hline Obesity II (75-148) & 119 & 1.84 & 35.0 & 51 \\
\hline Obesity V (108-224) & 163 & 1.78 & 51.4 & 58 \\
\hline
\end{tabular}

\section{Seat Foundation}

The seat foundation of upholstered furniture usually consists of a wooden base frame and a seat cushion. The seat base frame can have a solid flat supporting surface, and a top surface area with springs. Seat cushions are commonly made of one or more different foams covered with fabric or leather materials. Figure 1 shows the configurations and dimensions of the two types of wooden seat base frames (spring and flat rigid panel-top) used in this experiment. The dimensions of the seat base frames were determined by getting an approximate average of the dimensions of sofas from three sofa manufactures.

Five evenly spaced Standard Wire Gauge no. 8 curved sinuous springs were installed on the top of the spring type seat base frame (as shown in Fig. 1b). The two different densities $\left(30.8 \mathrm{~kg} / \mathrm{m}^{3}\right.$ and $\left.33.3 \mathrm{~kg} / \mathrm{m}^{3}\right)$ of foam block material used in this experiment were supplied by the Heritage Home Group, LLC (Highpoint, NC).

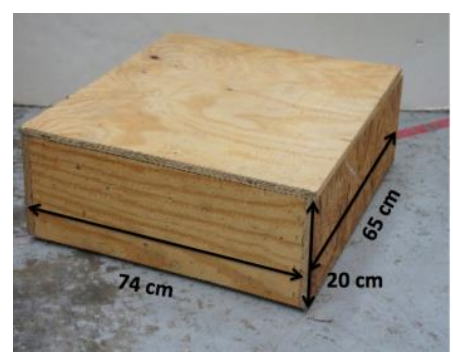

(a)

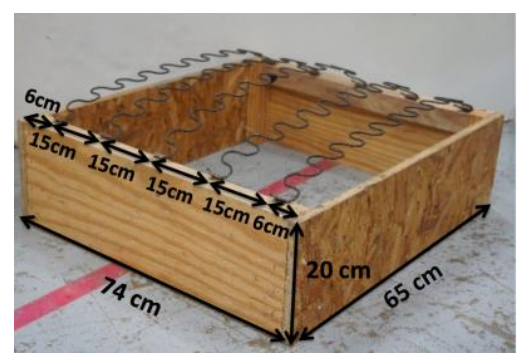

(b)

Fig. 1. Illustration of the seat base frames used in this study: (a) solid panel base frame; (b) curved sinuous spring base frame

\section{Experimental Design}

The basic compressive properties of the two foam densities $\left(30.8 \mathrm{~kg} / \mathrm{m}^{3}\right.$ and 33.3 $\mathrm{kg} / \mathrm{m}^{3}$ ) were evaluated through testing foam blocks $(10 \mathrm{~cm}$ wide by $10 \mathrm{~cm}$ long by $10 \mathrm{~cm}$ thick). Each of the foam densities was tested in triplicate. 
A complete $6 \times 2 \times 2$ factorial experiment was conducted to evaluate three factors that affect the compressive load-deformation behavior of the seat foundations of upholstered furniture. The three factors were indenter diameter $(20 \mathrm{~cm}, 30 \mathrm{~cm}, 36 \mathrm{~cm}, 41$ $\mathrm{cm}, 51 \mathrm{~cm}$, and $58 \mathrm{~cm}$ ), foam density $\left(30.8 \mathrm{~kg} / \mathrm{m}^{3}\right.$ and $\left.33.3 \mathrm{~kg} / \mathrm{m}^{3}\right)$, and seat base type (panel and spring). The foam blocks used in this study measured $61 \mathrm{~cm}$ long $\times 61 \mathrm{~cm}$ wide $\times 10$ $\mathrm{cm}$ thick, and each of the 24 experimental combinations were performed in triplicate.

The five indenter diameters $(30 \mathrm{~cm}, 36 \mathrm{~cm}, 41 \mathrm{~cm}, 51 \mathrm{~cm}$, and $58 \mathrm{~cm})$ were used in reference to the hip widths measured in this study (as shown in Table 1). These five indenter diameters represented five different buttock sizes, which corresponded to five different levels of BMI. The standard indenter with a diameter of $20 \mathrm{~cm}$ (according to ASTM standard 3574-17 (2017)) was included in this study.

\section{Testing}

All compressive property tests on the foam materials and seat foundations were performed with a hydraulic SATEC (Norwood, MA) universal testing machine in accordance with ASTM standard D3574-17 (2017). The loading speed was $0.85 \mathrm{~mm} / \mathrm{s}$. Figure 2 showed the setup for evaluating the basic compressive properties of the foam materials.

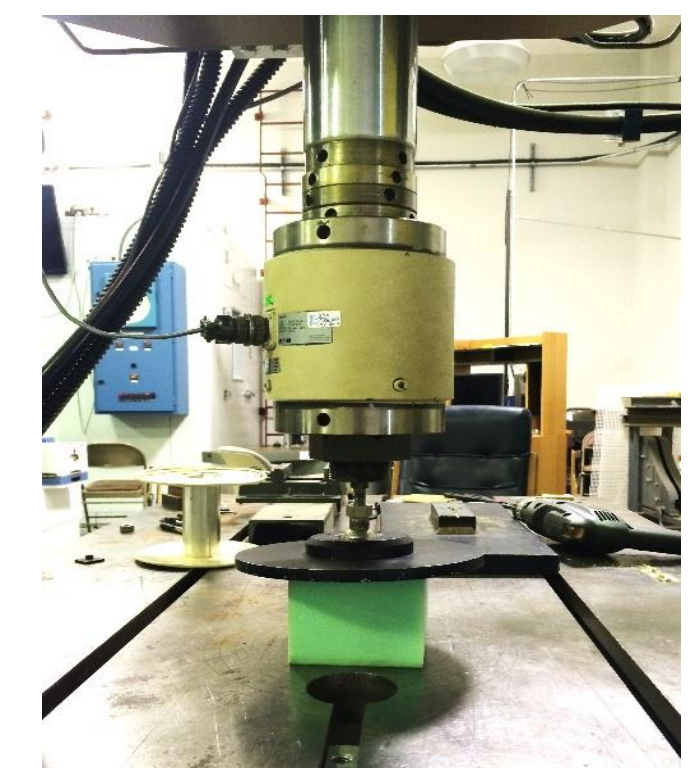

Fig. 2. Setup for evaluating the basic compressive properties of foam materials used in this study

Figure 3 showed the setup for measuring the compressive load-deformation properties of the seat foundation. Figure 4 illustrated six flat loading indenters, which included the $20 \mathrm{~cm}$ diameter standard metal indenter and the five wooden indenters made of $18 \mathrm{~mm}$ thick five-ply pine plywood.

All foams were conditioned in an EMC chamber prior to testing, which was controlled at $23{ }^{\circ} \mathrm{C} \pm 2{ }^{\circ} \mathrm{C}$ and $50 \% \pm 5 \%$ relative humidity (according to ASTM standard 3574-17 (2017)). For the load-deformation test, each specimen was preflexed by compressing it twice to $80 \%$ of its original thickness at a cross-head speed of $0.42 \mathrm{~mm} / \mathrm{s}$. The specimen was then allowed to rest $6 \mathrm{~min} \pm 1 \mathrm{~min}$ prior to beginning the formal test. Afterwards, the specimen was compressed to $75 \%$ of its original thickness at a speed of 
$0.85 \mathrm{~mm} / \mathrm{s}$, then allowed to rest $60 \mathrm{~s} \pm 3 \mathrm{~s}$ while the force drifted. The indenter was then raised at a speed of $0.85 \mathrm{~mm} / \mathrm{s}$ until it was no longer in contact with the specimen.

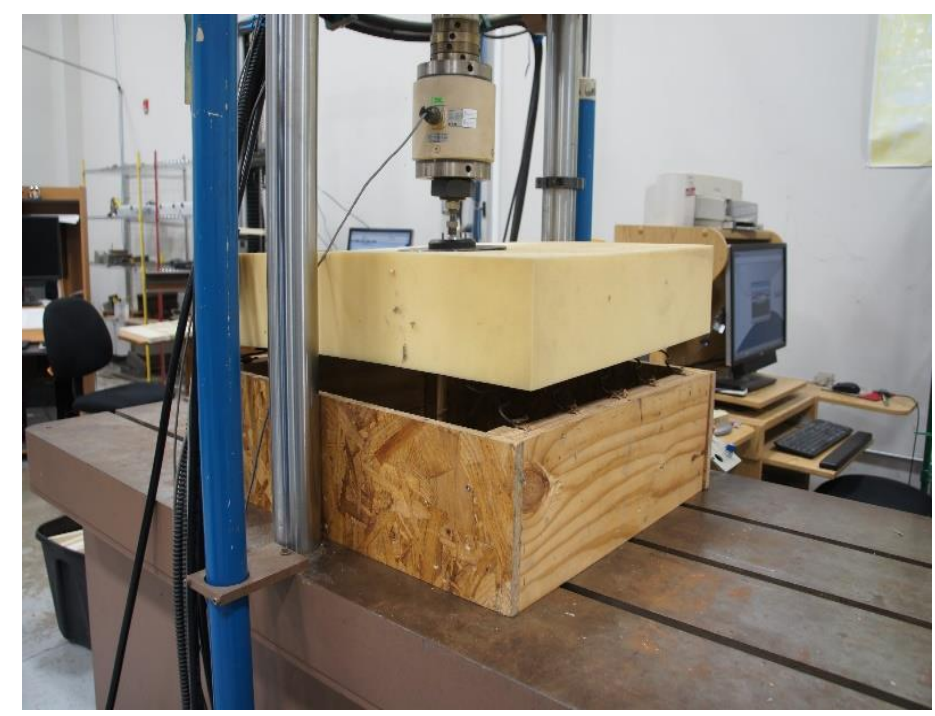

Fig. 3. Test setup for evaluating the compressive load-deformation property of a seat foundation
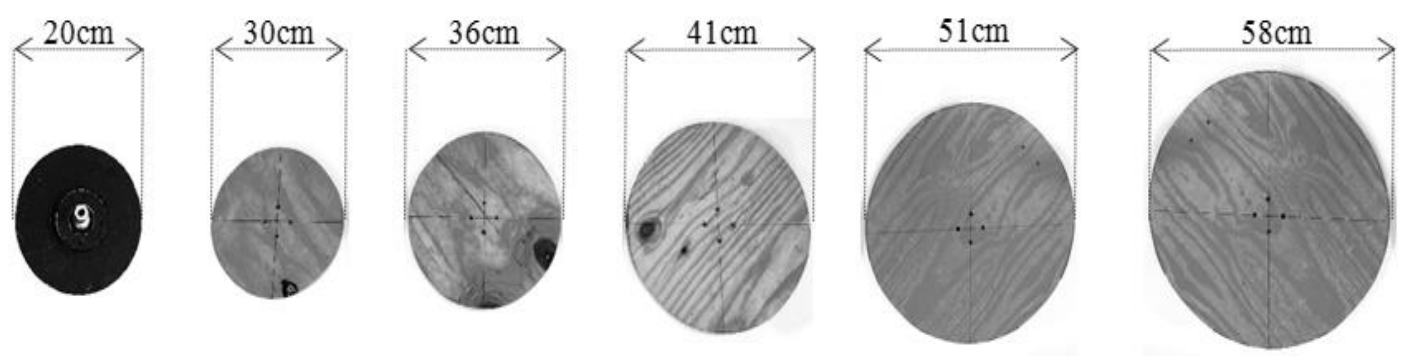

Fig. 4. The six indenters used in this experiment, including one metal and five wooden indenters

\section{Statistical analysis}

First, a three-factor analysis of variance (ANOVA) general linear model (GLM) procedure was performed to analyze the main effects and their interactions in terms of the compressive load-deformation properties of the tested seat foundations evaluated in this study. This was followed by mean comparisons using the protected least significant difference (LSD) multiple comparisons procedure to determine if any significant interactions were identified. All statistical analyses were performed at the $5 \%$ significance level.

\section{RESULTS AND DISCUSSION}

\section{Basic Compressive Properties of the Foams}

Figure 5 shows a typical three-phase stress-strain curve of the tested foam blocks. The three typical phases, which included phase I (the first linear region), phase II (the plateau region is the second linear portion, which exhibited reduced stiffness in comparison to the stiffness of the phase I), and phase III (the densification region, which exhibited a 
nonlinearity behavior with a sharp increase in materials stiffness), could be identified for all the stress-strain curves of the evaluated foam materials. Phase I accounted for $5 \%$ of the entire deformation, which was caused by the elastic deformation of the cell walls of the foam materials. The continued loading into phase II caused the foam cell walls to lose their stability and resulted in large deformation, which removed the air from intercellular spaces. In phase III, the deformed cell walls of the foam materials resulted in a considerable increase in its stiffness. The stiffness (elastic modulus) levels of the three phases were represented by $E_{1}, E_{2}$, and $E_{3}$, respectively. Table 2 summarized the means of these critical values and their comparisons performed using a LSD multiple comparisons procedure. The mean comparison results indicated that the high-density foam materials used in this experiment had significantly higher stiffness values than the low density ones for all three phases as shown in Table 2. Therefore, the stiffness of a foam material, i.e., a low or high stiffness foam, will be referenced for the rest discussion instead of its density.

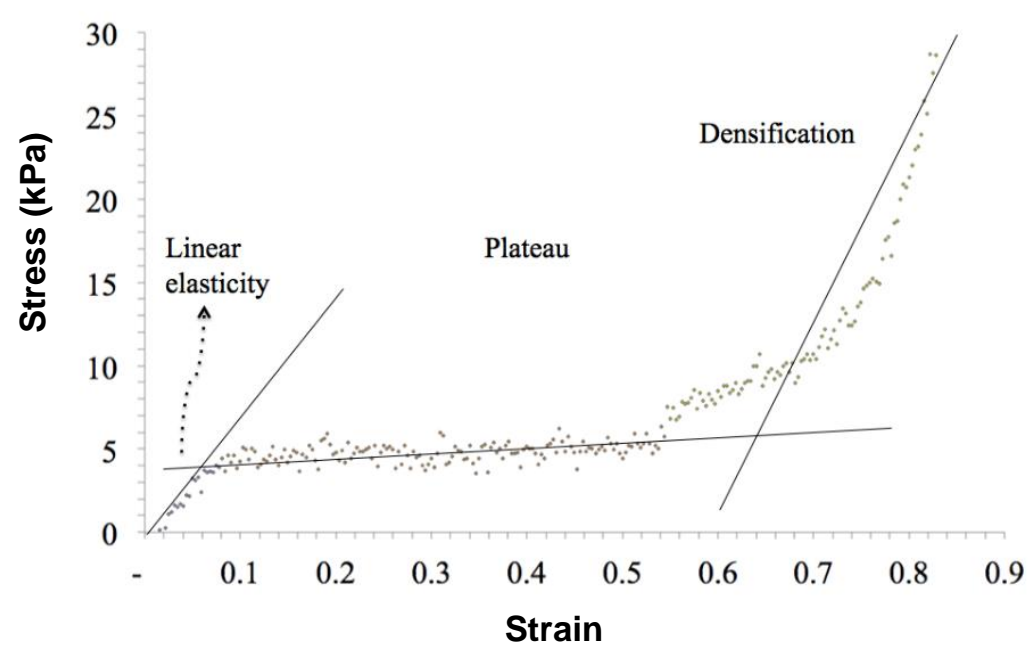

Fig. 5. A typical stress-strain curve of the tested foam blocks

Table 2. Summary of the Mean Stiffness Values for the Three Phases of the Two Foam Densities Evaluated in this Study

\begin{tabular}{|c|c|c|c|c|}
\hline \multirow{2}{*}{$\begin{array}{c}\text { Stiffness Value } \\
(\mathrm{kPa})\end{array}$} & \multicolumn{2}{|c|}{ Foam Density $\left(\mathrm{kg} / \mathrm{m}^{3}\right)$} & p-values & LSD values \\
\cline { 2 - 5 } & 30.8 & 33.3 & & \\
\hline$E_{1}$ & $36(11) \mathrm{B}$ & $67(2) \mathrm{A}$ & 0.0002 & 6.63 \\
\hline$E_{2}$ & $6(3) \mathrm{B}$ & $8(3) \mathrm{A}$ & 0.0005 & 0.48 \\
\hline$E_{3}$ & $398(1) \mathrm{B}$ & $432(1) \mathrm{A}$ & 0.0002 & 4.12 \\
\hline
\end{tabular}

Note: Values in parentheses are the coefficients of variation (percentages). Two means in each row not followed by a common letter are significantly different one from another at the $5 \%$ significance level.

\section{Compressive Properties of the Seat Foundation}

Figure 6 shows typical load-deformation curves of the evaluated seat foundations in this study. These curves also exhibited three well defined phases similar to the foam materials alone: linear elasticity, plateau, and densification. The average slope, i.e., the spring constant, for each region (linear elasticity, plateau, and densification) were expressed as $K_{1}, K_{2}$, and $K_{3}$, respectively. The least square linear regression technique was 
used to derive these slope values and the mean values of the coefficients of determination $\left(\mathrm{R}^{2}\right)$ of all regression fitting lines ranged from 0.65 to 0.99 .

The seat foundations with a panel type seat base had its deformation in the linear elasticity region account for $5 \%$ of the entire deformation (as shown in Fig. 6a and Fig. $6 \mathrm{~b}$ ), while the spring type seat base had its elasticity region account for $20 \%$ of the entire deformation (as shown in Fig. 6c and Fig. 6d).

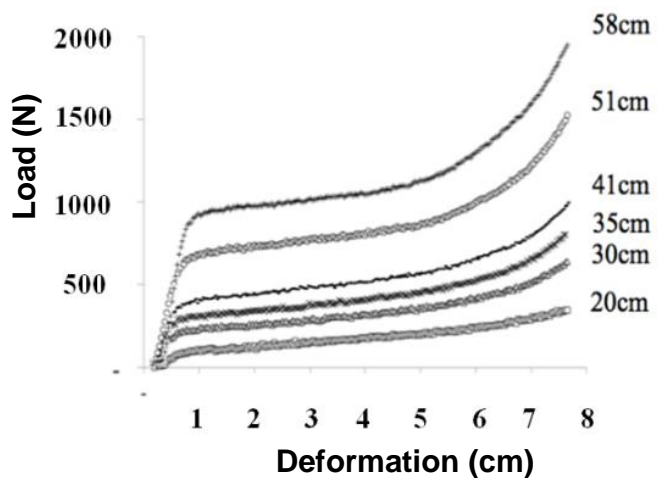

a)

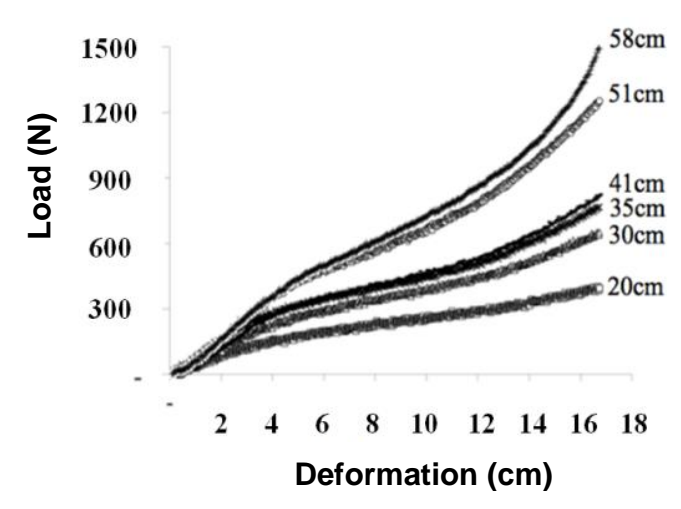

c)

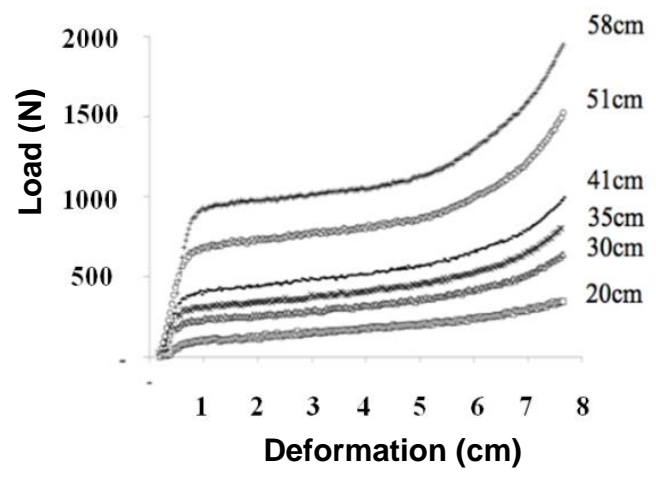

b)

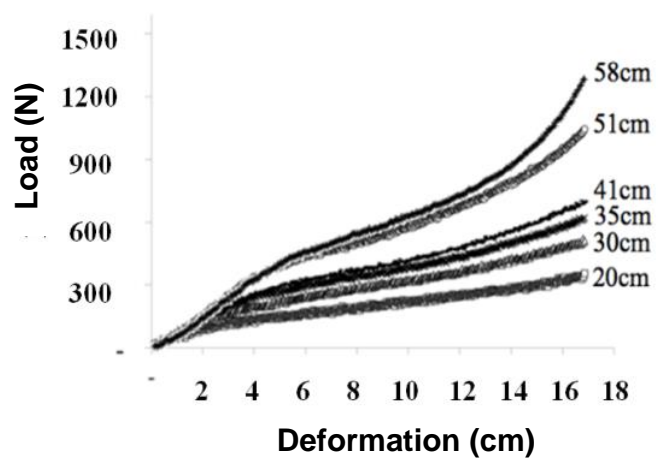

d)

Fig. 6. Typical load-deformation curves of the seat foundations evaluated with different indenter diameters in this study for each of the following experimental combinations: a) low stiffness foam with a panel type seat base; b) high stiffness foam with a panel type seat base; $c$ ) low stiffness foam with a spring type seat base; and d) high stiffness foam with a spring type seat base.

\section{Mean Comparisons}

Table 3 summarizes the mean values of $K_{1}, K_{2}$, and $K_{3}$ for each experimental combination of indenter diameter, foam stiffness, and seat base type. Table 4 summarizes the ANOVA results obtained from the GLM procedure performed for each of the three evaluated properties of the seat foundations, which indicated that the three-way interaction for each $K_{1}, K_{2}$, and $K_{3}$ value were not significant as shown in Table 4 . The effects of the three evaluated factors on the three critical properties were analyzed by considering the non-significant three-way interactions, because the nature of the conclusions from the interpretations of the primary effects were dependent on the relative magnitudes of the interactions and individual main effects. Tables 3, 5, and 6 summarize the mean comparisons of the $K_{1}, K_{2}$, and $K_{3}$ values for the indenter diameter, foam stiffness, and seat base type, respectively. These results were based on a one-way classification of the 24 treatment combinations created with respect to the three-factor interaction for each of the 
$K_{1}, K_{2}$, and $K_{3}$ data-sets and the mean comparisons for each of three data-sets using a single LSD value $(118.92 \mathrm{~N} / \mathrm{cm}, 9.17 \mathrm{~N} / \mathrm{cm}$, and $88.19 \mathrm{~N} / \mathrm{cm}$, respectively). In addition, the ratios of $K_{1}$ to $K_{2}$ and $K_{3}$ to $K_{2}$ for the indenter diameters with each combination of foam stiffness and seat base type were calculated and summarized in Table 7.

Table 3. Summary of the Mean Values of the Average Spring Constants of the Seat Foundations $K_{1}, K_{2}$, and $K_{3}$ and their Mean Comparisons for the Indenter Diameter Level Within Each Combination of Foam Stiffness and Seat Base Type

\begin{tabular}{|c|c|c|c|c|c|c|c|c|}
\hline \multirow{3}{*}{$\begin{array}{l}\text { Spring } \\
\text { Constant }\end{array}$} & \multirow{3}{*}{$\begin{array}{l}\text { Foam } \\
\text { Stiffness }\end{array}$} & \multirow{3}{*}{$\begin{array}{l}\text { Base } \\
\text { Type }\end{array}$} & \multicolumn{6}{|c|}{ Indenter Diameter (cm) } \\
\hline & & & 20 & 30 & 36 & 41 & 51 & 58 \\
\hline & & & & --------- & 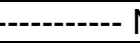 & $\mathrm{cm}-\cdots$ & 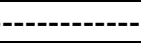 & \\
\hline \multirow{4}{*}{$K_{1}$} & \multirow{2}{*}{ Low } & Panel & $\begin{array}{l}254.7 \\
(5) \mathrm{F}^{\star}\end{array}$ & $\begin{array}{l}507.2 \\
(16) \mathrm{E}\end{array}$ & $\begin{array}{l}726.9 \\
(8) D\end{array}$ & $\begin{array}{l}929.3 \\
(2) \mathrm{C}\end{array}$ & $\begin{array}{c}1402.2 \\
\text { (1) B }\end{array}$ & $\begin{array}{l}2130.9 \\
(11) A\end{array}$ \\
\hline & & Spring & $\begin{array}{l}40.9 \\
\text { (1) A }\end{array}$ & $\begin{array}{l}52.3 \\
\text { (7) A }\end{array}$ & $\begin{array}{l}64.8 \\
\text { (1) A }\end{array}$ & $\begin{array}{l}72.1 \\
\text { (3) } A\end{array}$ & $\begin{array}{l}85.3 \\
\text { (3) A }\end{array}$ & $\begin{array}{l}82.7 \\
(4) A\end{array}$ \\
\hline & \multirow{2}{*}{ High } & Panel & $\begin{array}{l}338.6 \\
(12) \mathrm{F}\end{array}$ & $\begin{array}{l}570.4 \\
\text { (2) } E\end{array}$ & $\begin{array}{l}762.7 \\
\text { (2) D }\end{array}$ & $\begin{array}{l}995.8 \\
\text { (5) C }\end{array}$ & $\begin{array}{c}1613.7 \\
\text { (4) B }\end{array}$ & $\begin{array}{c}2188.9 \\
\text { (4) A }\end{array}$ \\
\hline & & Spring & $\begin{array}{l}42.4 \\
\text { (1) } \mathrm{A}\end{array}$ & $\begin{array}{l}60.4 \\
\text { (1) A }\end{array}$ & $\begin{array}{l}75.7 \\
\text { (1) A }\end{array}$ & $\begin{array}{c}74.4 \\
(11) \mathrm{A}\end{array}$ & $\begin{array}{l}94.2 \\
\text { (6) A }\end{array}$ & $\begin{array}{c}96 \\
(2) A\end{array}$ \\
\hline \multirow{4}{*}{$K_{2}$} & \multirow{2}{*}{ Low } & Panel & $\begin{array}{l}25.1 \\
\text { (5) B }\end{array}$ & $\begin{array}{c}34 \\
\text { (13) } A B\end{array}$ & $\begin{array}{c}34.4 \\
\text { (1) } \mathrm{AB}\end{array}$ & $\begin{array}{l}37.4 \\
\text { (1) A }\end{array}$ & $\begin{array}{l}40.3 \\
\text { (4) A }\end{array}$ & $\begin{array}{l}38.2 \\
\text { (9) A }\end{array}$ \\
\hline & & Spring & $\begin{array}{l}14.8 \\
\text { (1) C }\end{array}$ & $\begin{array}{l}20.5 \\
\text { (3) B }\end{array}$ & $\begin{array}{l}24.2 \\
\text { (2) B }\end{array}$ & $\begin{array}{l}27.8 \\
\text { (1) B }\end{array}$ & $\begin{array}{c}41 \\
\text { (6) A }\end{array}$ & $\begin{array}{l}47.9 \\
(4) A\end{array}$ \\
\hline & \multirow{2}{*}{ High } & Panel & $\begin{array}{c}33.2 \\
(14) C\end{array}$ & $\begin{array}{c}41.8 \\
(12) \mathrm{C}\end{array}$ & $\begin{array}{c}46 \\
(15) \mathrm{BC}\end{array}$ & $\begin{array}{c}51.5 \\
(20) \mathrm{B}\end{array}$ & $\begin{array}{c}55.1 \\
(23) \mathrm{AB}\end{array}$ & $\begin{array}{l}61.5 \\
\text { (3) A }\end{array}$ \\
\hline & & Spring & $\begin{array}{l}17.2 \\
\text { (5) C }\end{array}$ & $\begin{array}{c}25.2 \\
(10) \mathrm{C}\end{array}$ & $\begin{array}{l}28.2 \\
\text { (4) C }\end{array}$ & $\begin{array}{c}28.4 \\
(14) \mathrm{C}\end{array}$ & $\begin{array}{l}51.1 \\
(1) \mathrm{B}\end{array}$ & $\begin{array}{c}68.5 \\
(12) A\end{array}$ \\
\hline \multirow{4}{*}{$K_{3}$} & \multirow{2}{*}{ Low } & Panel & $\begin{array}{l}70.9 \\
\text { (1) C }\end{array}$ & $\begin{array}{c}123.9 \\
(19) \mathrm{BC}\end{array}$ & $\begin{array}{l}150.3 \\
\text { (1) B }\end{array}$ & $\begin{array}{l}167 \\
\text { (3) B }\end{array}$ & $\begin{array}{l}248.5 \\
\text { (6) } \mathrm{AB}\end{array}$ & $\begin{array}{l}315.4 \\
\text { (6) A }\end{array}$ \\
\hline & & Spring & $\begin{array}{c}26 \\
(4) C\end{array}$ & $\begin{array}{l}46.8 \\
\text { (8) C }\end{array}$ & $\begin{array}{l}53.5 \\
\text { (1) C }\end{array}$ & $\begin{array}{c}70.9 \\
\text { (3) } \mathrm{BC}\end{array}$ & $\begin{array}{l}145.4 \\
(10) \mathrm{B}\end{array}$ & $\begin{array}{l}323.8 \\
(24) A\end{array}$ \\
\hline & \multirow{2}{*}{ High } & Panel & $\begin{array}{c}81.4 \\
(10) \mathrm{E}\end{array}$ & $\begin{array}{l}161.3 \\
\text { (1) DE }\end{array}$ & $\begin{array}{c}197 \\
\text { (8) CD }\end{array}$ & $\begin{array}{l}253 \\
\text { (2) C }\end{array}$ & $\begin{array}{l}377.3 \\
\text { (1) B }\end{array}$ & $\begin{array}{l}536.5 \\
\text { (13) A }\end{array}$ \\
\hline & & Spring & $\begin{array}{c}33.7 \\
(14) \mathrm{C}\end{array}$ & $\begin{array}{l}51.2 \\
\text { (1) C }\end{array}$ & $\begin{array}{c}62 \\
\text { (9) BC }\end{array}$ & $\begin{array}{l}70.8 \\
\text { (4) } \mathrm{B}\end{array}$ & $\begin{array}{l}128.1 \\
(27) \mathrm{B}\end{array}$ & $\begin{array}{l}387.7 \\
(14) \mathrm{A}\end{array}$ \\
\hline
\end{tabular}

Table 4. Summary of the Analysis of Variance (ANOVA) Results Obtained from the General Linear Model (GLM) Procedure Performed on the Three Factors for Each of the $K_{1}, K_{2}$, and $K_{3}$ Data-sets

\begin{tabular}{|c|c|c|c|c|c|c|}
\hline \multirow{2}{*}{ Source } & \multicolumn{7}{|c|}{ Spring Constant } \\
\cline { 2 - 7 } & \multicolumn{2}{|c|}{$K_{1}$} & \multicolumn{2}{c|}{$K_{2}$} & \multicolumn{2}{c|}{$K_{3}$} \\
\cline { 2 - 7 } & $F$-value & $p$-value & $F$-value & $p$-value & $F$-value & $p$-value \\
\hline Indenter & 299.85 & $<.0001$ & 53.03 & $<.0001$ & 65.57 & $<.0001$ \\
\hline Foam & 7.99 & 0.0093 & 62.88 & $<.0001$ & 16.3 & 0.0005 \\
\hline Indenter $\times$ Foam & 0.6 & 0.6996 & 3.99 & 0.0089 & 2.55 & 0.0546 \\
\hline Seat & 3365.99 & $<.0001$ & 45.25 & $<.0001$ & 75.11 & $<.0001$ \\
\hline Indenter $\times$ Seat & 271.65 & $<.0001$ & 9.88 & $<.0001$ & 2.43 & 0.0641 \\
\hline Foam $\times$ Seat & 5.64 & 0.0259 & 5.87 & 0.0233 & 9.8 & 0.0045 \\
\hline Indenter $\times$ Foam $\times$ Seat & 0.61 & 0.6952 & 0.4 & 0.8425 & 1.11 & 0.382 \\
\hline
\end{tabular}


Table 5. Mean Comparisons of the Spring Constant Values for the Foam Stiffness for Each Combination of Indenter Diameter and Seat Base Type

\begin{tabular}{|c|c|c|c|c|c|c|c|}
\hline \multirow{5}{*}{$\begin{array}{c}\text { Indenter } \\
\text { Diameter }(\mathrm{cm})\end{array}$} & \multirow{5}{*}{ Base Type } & \multicolumn{6}{|c|}{ Spring constant } \\
\hline & & \multicolumn{2}{|c|}{$K_{1}$} & \multicolumn{2}{|c|}{$K_{2}$} & \multicolumn{2}{|c|}{$K_{3}$} \\
\hline & & \multicolumn{2}{|c|}{ Foam Stiffness } & \multicolumn{2}{|c|}{ Foam Stiffness } & \multicolumn{2}{|c|}{ Foam Stiffness } \\
\hline & & Low & High & Low & High & Low & High \\
\hline & & \multicolumn{6}{|c|}{ 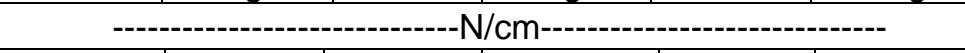 } \\
\hline \multirow{2}{*}{20} & Panel & $254.7 A^{*}$ & $338.6 \mathrm{~A}$ & $25.1 \mathrm{~A}$ & $33.2 \mathrm{~A}$ & $70.9 \mathrm{~A}$ & $81.4 \mathrm{~A}$ \\
\hline & Spring & $40.9 \mathrm{~A}$ & $42.4 \mathrm{~A}$ & $14.8 \mathrm{~A}$ & $17.2 \mathrm{~A}$ & $26 \mathrm{~A}$ & $33.7 \mathrm{~A}$ \\
\hline \multirow{2}{*}{30} & Panel & $507.2 \mathrm{~A}$ & $570.4 \mathrm{~A}$ & $34.0 \mathrm{~A}$ & $41.8 \mathrm{~A}$ & $124 \mathrm{~A}$ & $161 \mathrm{~A}$ \\
\hline & Spring & $52.3 \mathrm{~A}$ & $60.4 \mathrm{~A}$ & $20.5 \mathrm{~A}$ & $25.2 \mathrm{~A}$ & $46.8 \mathrm{~A}$ & $51.2 \mathrm{~A}$ \\
\hline \multirow{2}{*}{36} & Panel & $726.9 \mathrm{~A}$ & $762.7 \mathrm{~A}$ & $34.4 \mathrm{~B}$ & $46 \mathrm{~A}$ & $150 \mathrm{~A}$ & $197 \mathrm{~A}$ \\
\hline & Spring & $64.8 \mathrm{~A}$ & $75.7 \mathrm{~A}$ & $24.2 \mathrm{~A}$ & $28.2 \mathrm{~A}$ & $53.5 \mathrm{~A}$ & $62 \mathrm{~A}$ \\
\hline \multirow{2}{*}{41} & Panel & $929.3 \mathrm{~A}$ & $995.8 \mathrm{~A}$ & $37.4 \mathrm{~B}$ & $51.5 \mathrm{~A}$ & $167 \mathrm{~A}$ & $253 \mathrm{~A}$ \\
\hline & Spring & $72.1 \mathrm{~A}$ & $74.4 \mathrm{~A}$ & $27.8 \mathrm{~A}$ & $28.4 \mathrm{~A}$ & $70.9 \mathrm{~A}$ & $70.8 \mathrm{~A}$ \\
\hline \multirow{2}{*}{51} & Panel & $1402 \mathrm{~B}$ & $1614 \mathrm{~A}$ & $40.3 \mathrm{~B}$ & $55.1 \mathrm{~A}$ & $249 \mathrm{~B}$ & $377 \mathrm{~A}$ \\
\hline & Spring & $85.3 \mathrm{~A}$ & $94.2 \mathrm{~A}$ & $41.0 \mathrm{~B}$ & $51.1 \mathrm{~A}$ & $145 \mathrm{~A}$ & $128 \mathrm{~A}$ \\
\hline \multirow{2}{*}{58} & Panel & $2131 \mathrm{~A}$ & $2189 \mathrm{~A}$ & $38.2 \mathrm{~B}$ & $61.5 \mathrm{~A}$ & $315 \mathrm{~A}$ & $537 \mathrm{~A}$ \\
\hline & Spring & $82.7 \mathrm{~A}$ & $96 \mathrm{~A}$ & $47.9 \mathrm{~B}$ & $68.5 \mathrm{~A}$ & $324 \mathrm{~A}$ & $388 \mathrm{~A}$ \\
\hline
\end{tabular}

Table 6. Mean Comparisons of the Spring Constant Values for the Seat Base Type for Each Combination of Indenter Diameter and Foam Stiffness

\begin{tabular}{|c|c|c|c|c|c|c|c|}
\hline \multirow{5}{*}{$\begin{array}{c}\text { Indenter } \\
\text { Diameter }(\mathrm{cm})\end{array}$} & \multirow{5}{*}{$\begin{array}{l}\text { Foam } \\
\text { Stiffness }\end{array}$} & \multicolumn{6}{|c|}{ Spring constant } \\
\hline & & \multirow{2}{*}{\multicolumn{2}{|c|}{$\frac{K_{1}}{\text { Base Type }}$}} & & & & \\
\hline & & & & \multicolumn{2}{|c|}{ Base Type } & \multicolumn{2}{|c|}{ Base Type } \\
\hline & & Panel & Spring & Panel & Spring & Panel & Spring \\
\hline & & \multicolumn{6}{|c|}{ 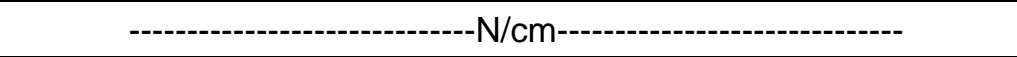 } \\
\hline \multirow{2}{*}{20} & Low & $254.7 A^{*}$ & $40.9 \mathrm{~B}$ & $25.1 \mathrm{~A}$ & $14.8 \mathrm{~B}$ & $70.9 \mathrm{~A}$ & $26 \mathrm{~A}$ \\
\hline & High & $338.6 \mathrm{~A}$ & $42.4 \mathrm{~B}$ & $33.2 \mathrm{~A}$ & $17.2 \mathrm{~B}$ & $81.4 \mathrm{~A}$ & $33.7 \mathrm{~A}$ \\
\hline \multirow{2}{*}{30} & Low & $507.2 \mathrm{~A}$ & $52.3 \mathrm{~B}$ & $34 \mathrm{~A}$ & $20.5 \mathrm{~B}$ & $123.9 \mathrm{~A}$ & $46.8 \mathrm{~A}$ \\
\hline & High & $570.4 \mathrm{~A}$ & $60.4 \mathrm{~B}$ & $41.8 \mathrm{~A}$ & $25.2 \mathrm{~B}$ & $161.3 \mathrm{~A}$ & $51.2 \mathrm{~B}$ \\
\hline \multirow{2}{*}{36} & Low & $726.9 \mathrm{~A}$ & $64.8 \mathrm{~B}$ & $34.4 \mathrm{~A}$ & $24.2 \mathrm{~B}$ & $150.3 \mathrm{~A}$ & $53.5 \mathrm{~B}$ \\
\hline & High & $762.7 \mathrm{~A}$ & $75.7 \mathrm{~B}$ & $46 \mathrm{~A}$ & $28.2 \mathrm{~B}$ & $197 \mathrm{~A}$ & $62 \mathrm{~B}$ \\
\hline \multirow{2}{*}{41} & Low & $929.3 \mathrm{~A}$ & $72.1 \mathrm{~B}$ & $37.4 \mathrm{~A}$ & $27.8 \mathrm{~B}$ & $167 \mathrm{~A}$ & $70.9 \mathrm{~B}$ \\
\hline & High & $995.8 \mathrm{~A}$ & $74.4 \mathrm{~B}$ & $51.5 \mathrm{~A}$ & $28.4 \mathrm{~B}$ & $253 \mathrm{~A}$ & $70.8 \mathrm{~B}$ \\
\hline \multirow{2}{*}{51} & Low & $1402 \mathrm{~A}$ & $85.3 \mathrm{~B}$ & $40.3 \mathrm{~A}$ & $41 \mathrm{~A}$ & $248.5 \mathrm{~A}$ & $145.4 \mathrm{~B}$ \\
\hline & High & $1614 \mathrm{~A}$ & $94.2 \mathrm{~B}$ & $55.1 \mathrm{~A}$ & $51.1 \mathrm{~A}$ & $377.3 \mathrm{~A}$ & $128.1 \mathrm{~B}$ \\
\hline \multirow{2}{*}{58} & Low & $2131 \mathrm{~A}$ & $82.7 \mathrm{~B}$ & $38.2 \mathrm{~B}$ & $47.9 \mathrm{~A}$ & $315.4 \mathrm{~A}$ & $323.8 \mathrm{~A}$ \\
\hline & High & $2189 A$ & $96 \mathrm{~B}$ & $61.5 \mathrm{~A}$ & $68.5 \mathrm{~A}$ & $536.5 \mathrm{~A}$ & $387.7 \mathrm{~B}$ \\
\hline
\end{tabular}


Table 7. Spring Constant Ratios for the Indenter Diameter for Each Combination of Foam Stiffness by Seat Base Type

\begin{tabular}{|c|c|c|c|c|c|c|c|}
\hline \multirow{2}{*}{ Spring Constant Ratio } & \multirow{2}{*}{ Foam Stiffness } & \multirow{2}{*}{ Base Type } & \multicolumn{5}{|c|}{ Indenter Diameter (cm) } \\
\hline & & & 30 & 36 & 41 & 51 & 58 \\
\hline \multirow{4}{*}{$K_{1}$ to $K_{2}$} & \multirow{2}{*}{ Low } & Panel & 15 & 21 & 25 & 35 & 56 \\
\hline & & Spring & 3 & 3 & 3 & 2 & 2 \\
\hline & \multirow{2}{*}{ High } & Panel & 14 & 17 & 19 & 29 & 36 \\
\hline & & Spring & 2 & 3 & 3 & 2 & 1 \\
\hline & & & & & & & \\
\hline \multirow{4}{*}{$K_{3}$ to $K_{2}$} & \multirow{2}{*}{ Low } & Panel & 4 & 4 & 4 & 6 & 8 \\
\hline & & Spring & 2 & 2 & 3 & 4 & 7 \\
\hline & \multirow{2}{*}{ High } & Panel & 4 & 4 & 5 & 7 & 9 \\
\hline & & Spring & 2 & 2 & 2 & 3 & 6 \\
\hline
\end{tabular}

\section{Indenter Diameter Effects}

Table 3 indicates that the indenter diameter had a significant influence on the spring constant $K_{l}$ values, which represented the slope of the first linear elasticity region when the seat foundation had a solid panel base, but it did not increase when the seat foundation had a spring base. Specifically, the $K_{l}$ values increased significantly as the indenter diameter increased when the seat foundation had a solid panel base but did not increase when the seat foundation had a spring base. These results indicated that the change in $K_{l}$ values were sensitive to changes in indenter diameter when a solid panel base was used for the seat foundation, but not when a spring base was used. This implied that when a sitter begins touching the seat surface of a seat foundation with a solid panel a sitter with pear body shape tended to feel that the seat was stiffer than a sitter of same weight but with an inverted triangle body shape. However, if a spring base was used, the two sitters will feel a similar level of stiffness from the seat foundation, because a seat foundation with a spring base tended to minimize the indenter diameter effect on the $K_{l}$ value. In general, it was observed that the standardized $20 \mathrm{~cm}$ testing indenter yielded a significantly lower $K_{l}$ value than the other five larger indenters evaluated in this study when a solid flat panel seat base was used together with foam as a seat foundation. However, when a spring seat base was used, the $20 \mathrm{~cm}$ indenter had a non-significant lower $K_{l}$ value than the other five larger indenters evaluated in this study.

In the plateau region, there were no significant differences in the spring constant $K_{2}$ values among the five indenters with a diameter larger than $30 \mathrm{~cm}$ if the seat foundation was a combination of low stiffness foam and a flat panel seat base. This indicated that the spring constant $K_{2}$ values were not sensitive to indenter diameter changes. This observation implied that if a group of sitters with BMI levels ranging from underweight to obesity V sit on the seat foundation, they will all feel a similar stiffness in the plateau region. However, if a high stiffness foam was used in a seat foundation with a flat panel seat base, significant increases in the spring constant $K_{2}$ values were observed when the indenter diameter increased from $30 \mathrm{~cm}$ to $41 \mathrm{~cm}$, and from $41 \mathrm{~cm}$ to $58 \mathrm{~cm}$. This which implied that underweight, overweight, and obesity $\mathrm{V}$ sitters might experience a different ride feel in terms of seat stiffness in the plateau region, i.e., underweight sitters might feel a softer ride, while the obesity $\mathrm{V}$ sitters might feel a harder ride. Meanwhile, there were no significant differences in the $K_{2}$ values between $30 \mathrm{~cm}$ and $36 \mathrm{~cm}$ indenters, $36 \mathrm{~cm}, 41 \mathrm{~cm}$, 
and $51 \mathrm{~cm}$ indenters, and between $51 \mathrm{~cm}$ and $58 \mathrm{~cm}$ indenters. This implied that the underweight and normal weight sitters could feel a similar sitting ride, i.e., a less stiff seat, while normal weight, overweight, and obesity II sitters could feel a similar sitting ride, i.e., a more stiff seat, and obesity II and obesity V sitters would experience a similar sitting ride, i.e., a more stiff seat in comparison to the rest of sitter groups. When a low stiffness foam was put on a spring seat base, there were no significant differences in the spring constant $K_{2}$ values among indenter diameters of $30 \mathrm{~cm}, 36 \mathrm{~cm}$, and $41 \mathrm{~cm}$, and diameters between $51 \mathrm{~cm}$ and $58 \mathrm{~cm}$, but the spring constant $K_{2}$ values of the two larger indenter diameters were significantly higher than the $K_{2}$ values of three smaller diameters. When the seat foundation had a high stiffness foam and a spring seat base, its spring constant $K_{2}$ values became more sensitive to indenter diameter changes for a larger range of diameters, i.e., greater or equal to $41 \mathrm{~cm}$ in comparison to smaller diameter indenters (less than $41 \mathrm{~cm}$ ). There were no significant differences in the $K_{2}$ values among $30 \mathrm{~cm}, 36 \mathrm{~cm}$, and $41 \mathrm{~cm}$ indenters, which implied that underweight, normal weight, and overweight sitters could feel a similar ride, i.e., less stiff, while obese sitters would feel a stiffer ride. The standardized $20-\mathrm{cm}$ indenter yielded a non-significantly lower $K_{2}$ value than the two larger $30 \mathrm{~cm}$ and $36 \mathrm{~cm}$ indenters, but had a significantly lower $K_{2}$ value than the three larger 41 $\mathrm{cm}, 51 \mathrm{~cm}$, and $58 \mathrm{~cm}$ indenters when the seat foundation had a solid flat panel seat base. The standardized $20-\mathrm{cm}$ indenter yielded a significantly lower $K_{2}$ value than all five larger indenters evaluated when a seat foundation was equipped with a low stiffness foam on top of a spring seat base, but had a non-significantly lower $K_{2}$ value than the three large $30 \mathrm{~cm}$, $36 \mathrm{~cm}$, and $41 \mathrm{~cm}$ indenters, but had a significantly lower $K_{2}$ value than the two larger 51 $\mathrm{cm}$ and $58 \mathrm{~cm}$ indenters when the seat foundation used a high stiffness foam.

In the densification region, the $K_{3}$ values (as shown in Table 3 ) increased as the indenter diameter increased, but the significances among the different indenter diameters were affected by not only the seat base type but also the foam stiffness. The $58 \mathrm{~cm}$ indenters had significantly higher $K_{3}$ values than the $K_{3}$ values of diameters less than $51 \mathrm{~cm}$, but not higher than the $K_{3}$ values of a $51 \mathrm{~cm}$ diameter, implying that obesity $\mathrm{V}$ sitters would experience a stiffer ride in comparison to the rest of the sitter groups. There were no significant differences in the $K_{3}$ values among the four indenter diameters less than $58 \mathrm{~cm}$ when the seat foundation had a low stiffness foam on a flat solid panel base. However, when a spring base was used instead of the panel base, the $51 \mathrm{~cm}$ indenter yielded a significantly higher $K_{3}$ value than the $36 \mathrm{~cm}$ and $30 \mathrm{~cm}$ indenters, but not significantly higher than the $41 \mathrm{~cm}$ indenter $K_{3}$ values; there were no significant differences in the $K_{3}$ value among the three indenters with a diameter less than $51 \mathrm{~cm}$. These observations indicated that the $K_{3}$ values of the low stiffness and solid panel base seat foundations were less sensitive to indenter diameter change but altering the seat base stiffness to a less stiff base could somehow change this sensitive. In another words, underweight, normal weight, overweight, and obesity II sitters would feel a similar seat stiffness in the densification region when they sit on a low stiffness and solid panel base seat foundation. However, an obesity II sitter would feel a significantly stiffer seat than the underweight and normal weight sitters, but not stiffer than an overweight sitter would feel if a spring seat base were used instead of a solid flat panel based. The $K_{3}$ values exhibited a different behavior when a high stiffness foam was used in the seat foundation in comparison to a low stiffness foam being used. In the high stiffness foam and solid flat panel seat foundation, the $K 3$ value was sensitive to indenter diameter change while the seat foundation with a spring seat base was less sensitive to indenter diameter change. The standardized $20 \mathrm{~cm}$ indenter yielded nonsignificantly lower $K_{3}$ values than the $30 \mathrm{~cm}$ indenter $K_{3}$ values but had significantly lower 
$K_{3}$ values than the indenters with a diameter larger than $30 \mathrm{~cm}$ when the seat foundation had a solid flat panel seat base. The standardized $20 \mathrm{~cm}$ indenter yielded non-significantly lower $K_{3}$ values than the three large $30 \mathrm{~cm}, 36 \mathrm{~cm}$, and $41 \mathrm{~cm}$ indenters, and yielded significantly lower $K_{2}$ values than the two larger $51 \mathrm{~cm}$ and $58 \mathrm{~cm}$ indenters when the seat foundation was equipped with a low stiffness foam on top of a spring seat base. The standardized $20 \mathrm{~cm}$ indenter yielded non-significantly lower $K_{3}$ values than the two large $30 \mathrm{~cm}$ and $36 \mathrm{~cm}$ indenters, and significantly lower $K_{2}$ values than the three larger $41 \mathrm{~cm}$, $51 \mathrm{~cm}$, and $58 \mathrm{~cm}$ indenters when the seat foundation had high stiffness foam.

Table 7 indicates that the $K_{1} / K_{2}$ ratios increased by a magnitude of 15 to 56 as the indenter diameter increased from $30 \mathrm{~cm}$ to $58 \mathrm{~cm}$ when a flat solid panel base was used, but the ratio increase ranged from 1 to 3 when a spring base was used. These observations implied that when a flat solid base was used, a sitter could feel a hard surface for a moment when the body started touching the seat surface, but this initial hard surface feeling would not occur when a spring base was used. The $K_{3} / K_{2}$ ratios indicated that the seat foundations with either a solid flat panel seat base or a spring seat base had a similar increasing trend in the $K_{3} / K_{2}$ ratios as the indenter diameter increased, i.e., the ratios are not dependent on the foam stiffness for a given seat base type. The ratios for the spring base seat foundations ranged from 2 to 7, which were lower than the solid flat panel base ratios (ranging from 4 to 9). These results implied that a seat foundation with a solid flat panel seat base tended to easily bottom-out in comparison to a spring seat base. In addition, it was observed that in general, for each foam stiffness and seat base type combination, the $K_{3} / K_{2}$ ratio tended to be constant for the three smaller indenter diameters $(30 \mathrm{~cm}, 36 \mathrm{~cm}$, and $41 \mathrm{~cm})$ but started its increasing trend when the indenter diameter was greater than $41 \mathrm{~cm}$. This increasing trend implied that a sitter with larger buttocks tended to easily bottom-up in comparison to a sitter with smaller buttocks.

\section{Foam Stiffness Effects}

Table 5 indicated that in general, the spring constant values of the seat foundations with high stiffness value foams were higher than those with low stiffness value foams. But these differences were not statistically significant for most of the $K_{1}$ and $K_{3}$ values, or for $K_{2}$ values at an indenter diameters smaller than $36 \mathrm{~cm}$ for panel base type seat foundations and $51 \mathrm{~cm}$ for spring base type seat foundations. In other words, the difference in the $K_{2}$ values between the seat foundations with a high and low stiffness foam did not become significant until the indenter diameter reached to $36 \mathrm{~cm}$ for panel base type seat foundations and $51 \mathrm{~cm}$ for spring base type seat foundations.

\section{Base Type Effects}

The mean comparisons (as shown in Table 6) indicated that the seat foundations with solid flat panel bases had significantly higher $K_{l}$ values than seat foundations with spring bases. Seat foundations with solid flat panel bases had significantly higher $K_{2}$ values than seat foundations with spring bases when subjected to indenters with a diameter less than $41 \mathrm{~cm}$, but were no longer significant when the indenter diameters were greater than $41 \mathrm{~cm}$. Seat foundations with solid flat panel bases had non-significantly higher $K_{3}$ values than seat foundations with spring bases when subjected to indenters with a diameter less than $30 \mathrm{~cm}$, but became significant when the indenter diameters were greater than $30 \mathrm{~cm}$.

Hu et al. (2020). "Cushioning of seat foundations," BioResources 15(4), 7992-8007. 


\section{Prediction Equation}

To quantify the effects of the indenter diameter, foam stiffness, and seat base type on the spring constants of the seat foundations $\left(K_{1}, K_{2}\right.$, and $\left.K_{3}\right)$ and to obtain the functional relationships between the individual spring constants and the parameters that might be practical for seat design purposes, the least squares regression technique was proposed to fit to the individual test data points, as shown in Eq. 1,

$$
K=\mathrm{ad} \times E^{c} \times \gamma^{d}
$$

where $K$ represents $K_{1}, K_{2}$, and $K_{3}(\mathrm{~N} / \mathrm{cm}), d$ is the indenter diameter (cm), $E$ is the foam stiffness $(\mathrm{N} / \mathrm{cm}), \gamma$ is the base type $(\gamma=1$ for flat panel bases and $\gamma=2$ for spring bases), and $a, b, c, d$ are regression fitting constants.

The regression analyses yielded the following significant power equations shown in Table 8, with $p$-values all less than 0.0001 and their coefficient of determination ranging from 0.84 to 0.98 for three spring constants.

Table 8. The Mean Values of the Derived Regression Constants and their Associated Coefficient of Determination ( $r^{2}$ Values) of the Three Power Equations Estimating the Three Spring Constants of the Seat Foundations Evaluated in the Study $\left(K_{1}, K_{2}\right.$, and $\left.K_{3}\right)$

\begin{tabular}{|c|c|c|c|c|c|}
\hline Spring Constant & $a$ & $b$ & $c$ & $d$ & $r^{2}$ \\
\hline$K_{1}$ & 0.758 & 1.304 & 0.177 & -3.645 & 0.98 \\
\hline$K_{2}$ & 0.534 & 0.835 & 1.269 & -0.439 & 0.84 \\
\hline$K_{3}$ & -4.221 & 1.82 & 2.264 & -1.232 & 0.90 \\
\hline
\end{tabular}

This indicated that the derived equations could be useful for predicting the mean stiffness of a seat foundation as a function of various factors, e.g., indenter diameter, foam material stiffness, and seat base type. In another words, the regression method proposed in this study could be a useful technique for deriving the quantitative relationship between the stiffness of a seat foundation consisting of a foam and seat base and its component characteristics. However, additional research needs to be done on this topic in order to validate this regression technique and also to identify other major factors that could be included.

\section{CONCLUSIONS}

1. The effects of the indenter diameter, foam stiffness, and seat base type on the compressive load-deformation behavior of seat foundations of upholstered furniture were investigated experimentally. Experimental results indicated that the loaddeformation curves of all tested seat foundations exhibited three typical regions of linear elasticity, plateau, and densification. Statistical analysis on the effects of the indenter diameter on the spring constants, which represented the average slopes of the lines in these three regions, indicated that the spring constant, $K_{l}$ (representing the slope of linear elasticity region) was influenced significantly by the indenter diameters when the seat foundation had a solid panel base, but was not influenced significantly when the seat foundation had a spring base. The spring constant, $K_{2}$ (representing the slope of plateau region) in general, increased as the indenter diameter increased, but the level 
of significance was affected by the foam stiffness and base type. The spring constant, $K_{3}$ (representing the slope of densification region) increased as the indenter diameter increased, but the level of significance among the different indenter diameters were also affected by not only seat base type but the foam material stiffness.

2. The spring constant values of the seat foundations that used high stiffness foams were in general higher than seat foundations with low stiffness foams, but these differences were mostly non-significant. Seat foundations that used solid flat panel bases had significantly higher $K_{1}$ values than seat foundations that used spring bases. Seat foundations that used solid flat panel bases had higher $K_{2}$ and $K_{3}$ values than seat foundations that used spring bases, but the level of significance was affected by the indenter diameter.

3. A regression technique was proposed to derive the power equations used for the estimation of the spring constants of a seat foundation as a function of the indenter diameters, foam material stiffness levels, and seat base types investigated in this study.

\section{ACKNOWLEDGMENTS}

This study was funded by the Zhejiang Natural Science Foundation (China) [Grant No. LQ18C160002], and the Xilinmen Furniture Co., Ltd. (Shaoxing, China) [Grant No. H20170306]. The authors are grateful for the support of the Heritage Home Group, LLC (Highpoint, NC) and Flexsteel Company (Dubuque, IA), for providing experimental materials for this study, and are also grateful for Mr. Bob Tackett at Mississippi State University for providing technical assistance to this project.

\section{REFERENCES CITED}

ASTM D3574-17 (2017). "Standard methods of testing flexible cellular materials-slab, bonded and molded urethane foams," ASTM International, West Conshohocken, PA.

Chen, Z., Li, W., Negahban, M., Saiter, J.-M., Delpouve, N., Tan, L., and Li, Z. (2017). "Approaching the upper bound of load capacity: Functional grading with inter penetrating polymer networks," Materials \& Design 137, 152-163. DOI: 10.1016/j.matdes.2017.10.019

Demirel, S., and Tuna, B. E. (2019a). "Constant-fatigue performance of different polyurethane foams for sitting purposes," Kastamonu University Journal of Forestry Faculty 19(2), 225-234. DOI: 10.17475/kastorman.626277

Demirel, S., and Tuna, B. E. (2019b). "Evaluation of the cyclic fatigue performance of polyurethane foam in different density and category," Polymer Testing $76,146-153$. DOI: $10.1016 /$ j.polymertesting.2019.03.019

Dionne, M.-J., Aubin, C.-E., Dansereau, J., and Aïssaoui, R. (1998). "Finite element modeling of a wheelchair seat cushion," Journal of Biomechanics 31(1), 177-177. DOI: 10.1016/S0021-9290(98)80356-4

Ebe, K., and Griffin, M. J. (2000). "Quantitative prediction of overall seat discomfort," Ergonomics 43(6), 791-806. DOI: 10.1080/001401300404751

Ebe, K., and Griffin, M. J. (2001). "Factors affecting static seat cushion comfort," Ergonomics 44(10), 901-921. DOI: 10.1080/00140130110064685 
Gao, W. M., Wang, L., Coffey, J. K., and Daver, F. (2018). "Understanding the scratch behaviour of polymeric materials with surface texture," Materials \& Design 146, 3848. DOI: 10.1016/j.matdes.2018.02.074

Grujicic, M., Pandurangan, B., Arakere, G., Bell, W. C., He, T., and Xie, X. (2009). "Seat-cushion and soft-tissue material modeling and a finite element investigation of the seating comfort for passenger-vehicle occupants," Material \& Design 30(10), 4273-4285. DOI: 10.1016/j.matdes.2009.04.028

Hu, L., Tackett, B., Tor, O., and Zhang, J. (2016). "Analysis of sitting forces on stationary chairs for daily activities," Ergonomics 59(4), 556-567. DOI: 10.1080/00140139.2015.1080311

Jucienè, M., and Vobolis, J. (2013). "Researching into the methodology for the evaluation of deformed soft furniture upholstery," International Journal of Clothing Science and Technology 25(1), 59-69. DOI: 10.1108/09556221311292219

Kim, D., Min, K., Park, H., and Park, J. (2014). "Measurement of the distributed dynamic stiffness of seats under compression to analyze dynamic characteristic of seats," in: Inter-noise and Noise-con Congress and Conference, 16-19 November, Melbourne, Australia, pp. 3650-3652.

Lee, J., and Ferraiuolo, P. (1993). Seat Comfort (SAE Technical Paper No: 930105), SAE International, Warrendale, PA. DOI: 10.4271/930105

Li, M. (2017). Load-deflection and Pressure Distribution of Upholstered Furniture Seat Foundations, Ph.D. Dissertation, Mississippi State University, Starkville, MS.

Li, M., Zhou, X., Wu, Z., and Zhang, J. (2018). "Factors on cushion stiffness of upholstered seat systems subjected to human weights," BioResources 13(3), 65426554. DOI: 10.15376/biores.13.3.6542-6554

Li, M., Wu, Z., Tackett, B., and Zhang, J. (2017). "Human and testing bag impact loads on stationary seating," Wood and Fiber Science 49(3), 1-16.

Oh, J. S., Kim, D. Y., Kim, H. Y., Lee, C. A., Bang, J. H., and Choi, K. Y. (2016). "Wrinkle prediction of seat cover considering cyclic loading-unloading with viscoelastic characteristics," Materials \& Design 109, 270-281.

DOI:10.1016/j.matdes.2016.07.040

Shen, W., and Vertiz, A. M. (1997). "Redefining seat comfort," (SAE Technical Paper No: 970597), SAE International, Warrendale, PA. DOI: 10.4271/970597

Sims, G. L. A., and Bennett, J. A. (1998). "Cushioning performance of flexible polyurethane foams," Polymer Engineering \& Science 38(1), 134-142. DOI: $10.1002 /$ pen.10173

Smardzewski, J. (2013). "New construction of mattress springs," Materials \& Design 49, 318-322. DOI: 10.1016/j.matdes.2013.01.041

Smardzewski, J., Prekrat, S., and Pervan, S. (2010). "Research of contact stresses between seat cushion and human body," Drvna Industrija 61(2), 95-101.

Sprigle, S., Chung, K.-C., and Brubaker, C. E. (1990a). "Factors affecting seat contour characteristics," Journal of Rehabilitation Research and Development 27(2),127-134. DOI: 10.1682/JRRD.1990.04.0127

Sprigle, S., Chung, K.-C., and Brubaker, C. E. (1990b). "Reduction of sitting pressures with custom contoured cushions," Journal of Rehabilitation Research and Development 27(2), 135-140. DOI: 10.1682/JRRD.1990.04.0135

Swearingen, J. J., Wheelwright, C. D., and Gamer, J. D. (1962). "An analysis of sitting areas and pressure of man," Civil Aeromedical Research Institute Report 62-1. Oklahoma, OK. 
Todd, B. A., Smith, S. L., and Bum, T. S. (1996). "Mechanical properties of open-cell foams," ASME (American Society of Mechanical Engineers), Materials Division (MD) 74, 201-202.

Todd, B. A., Smith, S. L., and Vongpaseuth T. (1998). "Polyurethane foams: Effects of specimen size when determining cushioning stiffness," Journal of Rehabilitation Research and Development 35(2), 219-224.

World Health Organization (2006). "Global database on body mass index," (http://apps.who.int/bmi/index.jsp?introPage=intro_3.html) Accessed 24 December 2017.

$\mathrm{Xu}, \mathrm{W}$., Wu, Z., and Zhang, J. (2015). "Compressive creep and recovery behaviors of seat cushions in upholstered furniture," Wood and Fiber Science 47(4), 431-444.

Article submitted: June 4, 2020; Peer review completed: July 12, 2020; Revised version received: August 12, 2020; Accepted: August 13, 2020; Published: September 4, 2020. DOI: $10.15376 /$ biores.15.4.7992-8007 